\title{
Online Brand Awareness. A Case-Study on Creating Associations and Attachment
}

\author{
Alina NECHITA (VINGAN), PhD \\ Faculty of Political, Administrative and Communication Sciences \\ Babeş-Bolyai University \\ E-mail: alinavingan@gmail.com
}

\begin{abstract}
A consistent online presence requires the existence of positive information only, or negative information that does not harm the image of the person or product. The success of the brand in medium term involves the existence of an online communication strategy of at least six months, avoiding negative associations and comments and ensuring a constant feedback from the target audience. A faster way to create brand awareness is the association with people or highly influential brands and with influencers on the same market. The evolution of Cluj-based brand EBS showed that association with other names, in order to gain notoriety in a certain community, does not necessarily imply choosing successful partners, but choosing partners that have symbolic value for specific groups in that community.
\end{abstract}

Keywords: Brand attachments; Brand in social media; Brand associations; Communication in social media; Brand influencers. 


\section{Introduction}

For consumers, unique brand elements like the name, logo, physical format, packaging, design or taste, although they form the structure of the actual brand, have no particular meaning when the brand is first released on the market and there is nothing associated it with (Plowman, Winchel 2016, p. 103). The brand develops over time and its development is based on several variables that are critical for the speed at which it will impose itself on the market: purchasing power, utility, the quantity of information that defines it, the quantity and consumption of advertising. Over time, the brand-defined product is associated with the brand's abstract and symbolic properties of the brand and the footprints left on the market by consumers, following their personal experiences. Thus, the brand evolves and gains significance and will, over time, surpass the primary meanings: depth and symbolic properties (Stuhlfaut, Yoo 2013, p. 83).

The study aims to support the hypothesis that a brand is, above all, a symbolic construction. Obviously, the economic, social or pragmatic justification of the brand is essential, but they are just the foundation on which the symbolic dimension is supported. Consequently, the creator of a brand will not be satisfied with the simple relationship between a manufacturer and a buyer; one will seek to transform the customer into a stable partner and to cultivate the customer's attachment to the brand and the values the brand represents. Digital era, with a lot of possibilities to communicate, offers various possibilities in this regard. It also imposes some specific requirements for good brand management. At the same time, it is important to highlight how a brand can be smartly and durably built by exploiting the resources made available by the online environment without recruiting PR or advertising specialists. It is a fact that suggests that genuine entrepreneurial spirit also includes PR management skills.

The case study is an interview with a renowned businessman who intuitively and successfully used brand promotion methods at a time when there was hardly any source of information in this area. The brand has become a local symbol and has shortly gained international recognition.

\section{Techniques to increase brand visibility}

\section{Brand appropriate social platform}

The long-term brand success depends on the communication specialist's capacity and talent to influence meanings and create new ones. The channel for transmitting brand information, advertising or marketing strategy also influences how the audience resonates with that product or service. The symbolic dimension of the brand and its attachment to it are amplified by taking into account the consumption habits of the target audience (Akrout, Nagy 2018). 
This theory is also supported by research published in 2010 by Ira Carlin demonstrating the role of new media in brand promotion. The migration of content from conventional media, to online media, and also the multimedia platforms, which represent in fact a unification of media types, have undermined the public's exposure to traditional advertising (Carlin 2010, pp. 2-4). Carlin's ideas come in addition to another research published in 2006 that claimed that target audience's experience with the product will also become more personal as the media used to convey advertising becomes more adapted to consumer behavior (Calder, Malthouse, Edward 2006, p. 356). Building the brand online means, above all, building the social media brand. In the virtual space, brand awareness increases proportionally with a correct involvement and funding of the brand. In April 2015, Entrepreneur.com posted an article about the Econsultancy research, which proved that $71 \%$ of brands had manifested their intention to invest more in social media in 2016, in order to build the brand's reputation and expand their audience (Agius 2015). More and more companies with famous brands invest significant amounts in social media, aiming to draw new, younger audiences, with higher purchasing power, contributing to the building of new brands and consolidating a known brand. Worldwide, there are currently many types of online and social platforms that a brand can select in order to promote and win notoriety. Depending on the country and the behavior of the audience, some social networks are more likely than others to have a good result in brand strategy.

In order to identify the type of social network appropriate for a certain brand, one must take into account the fact that Facebook has by far the potential for successfully launching new brands (Plowman, Winchel 2016, p. 27). According to the charts published by Statista in the first months of 2018, we have a clear picture of the number of active users (in millions) with Facebook ruling supreme. With over 1.86 billion monthly active users, social network Facebook is currently the market leader in terms of reach and scope (Statista.com 2017). With over 2 billion active users it holds the majority market share. Google's YouTube is second with Facebook-owned, WhatsApp and Messenger not far behind. Second as frequency of use and audience, Youtube is a social network mainly used to build personal image (vlog, video, actors, music industry artists, etc.). In the case of product brands, Youtube is used as secondary promotional media, due to the video support it provides. On Instagram in 2015, there were approximately more than 77.6 million active users in the United States. This figure is projected to surpass 111 million in 2019, according Statista.com. Instagram is most popular with teens and young Millennials - this holds true in the United States where more than half of Instagram's user base is between 18 and 29 years old. Instagrams content consists of photos, video and short texts. This communication channel is successfully used for brand awareness, particularly for those brands that rely on visuals (clothing and footwear products, etc.). 
In Romania, a proper environment for brand promotion is the blogosphere and the group communities created on Facebook, which are the most successful spaces for launching, promoting and building a brand. Pinterest is another example of social media, a network which is appropriate for promoting products and brands. The content is focused on photos, which can contain links to various websites and articles. The social site's strong user engagement with popular topics and themes such as fashion, home, garden and DIY and subsequently, relevant brands and influencers. Social networking site Pinterest was the fastest site in history to reach 10 million unique monthly visitors and high user engagement metrics (Statista.com). In October 2016, more than six years after launch, Pinterest reported 150 million monthly active Pinterest users worldwide (Statista.com). This is a good environment for visibility, expanding fanbases and creating beneficial associations for the brand. Finally, for business to business operators, LinkedIn is a good choice, if the aim is to promote complementary services between corporations or between a corporation and a smaller player from the same market.

There are many experienced social media practitioners and social media marketers who recommend in order to create a brand with a good reputation, to use simple texts, with a strong message to the target audience (Percy 2014, p. 19). Regardless of the format of such messages, their content has to be easily consumed and cover general interest topics. Each word or image included in the content of the message has to support the image of the brand. Humorous messages, accompanied by impactful images and consistent with the message of the text are recommended. Regarding this last statement, US social media specialists have shown that humor can establish social connections much faster and longer than other types of messages, especially because humor triggers positive feelings (Pascale 2015). In order to best select the appropriate content for the brand, analyzing the social media or website audience is recommended. In many cases, static or motion pictures can trigger a better content, compared to a text post, regardless of the level of the writing. An overall perspective on the activity from a certain field also involves the analysis of the accounts and the impact of the competitors' posts from the same market or from similar fields. Thus, it is preferably to create original, short-form content with selected images, in line with the brand strategy and public preference. Practice also demonstrated that an attractive social media post can also be a successful idea, taken over and modified in relation to the profile of the account and the expectations of the audience.

The importance of the personal interaction in social media

\section{Online communities and influencers creates brand awareness}

A blogger with a significant audience is a very good option as brand promoter for any company. In the blogosphere, brand awareness is built on the seen, tried, 
recommended principle. In order to recommend a product or a service, it is assumed that the blogger, as opinion leader in the community created by him/her (influencer), tests himself/herself such product/service, applies the filter of personal experience and issues a verdict having the role of defining experience for that particular community. Although highly biased, the method is more and more frequent and successful, particularly in niche communities (landscaping tools, beauticians, photographers, fitness fans, etc.) By applying the same principle, the principle of community leader, brand awareness is built in Facebook group communities.

Although a viral content was created, in the absence of a well-known brand to associate it with, the impact of its message will soon become null. An audience can also be created through high quality content, but this process is time consuming. Online marketers recommend for a quicker way to create reputation to associate the brand with influential persons or other brands in the field (Cova, Pace 2006, p. 105). For this purpose, win-win strategies can be adopted, protocols can be established for promoting well-known brands, through valuable online content, or famous brands can be mentioned and labeled while promoting valuable content. In this last case, sending an official e-mail, mentioning the online appearance is also recommended. The goal is to have such post taken over by an influential brand and shared through its own channels, thus contributing to brand development and awareness. The consistency of such actions will draw the attention of large operators, and will in time generate the expected reactions.

According to Danielle Wiley, Founder and CEO of Sway Group, an influencer marketing agency in the SF Bay Area, most companies tend to measure influencer campaigns based on reach, impressions and engagement rather than the end sale. And influencer-shared content is often used as an introduction to a product or service. In the long run, the techniques of creating brand awareness, applied by influencers, have become more subtle. Offering a personal example, adding even more privacy and using storytelling as a genre, the involvement of influencers in promoting brands is even more successful. For example, there are influencers who use images to demonstrate the usefulness of a product or the way they use it, and these approaches are successful (Wiley 2018). Influencer's marketing is a very good strategy for selling a product or service. On the one hand, he quickly spreads the information to a large number of potential clients, and on the other hand his personal experience, the recommendation made to the community he represents is the value of advice received from a very convincing friend. The influencers help create a domino effect of potential new customers becoming familiar with your brand (Crowe 2017).

Mentions and links often expand beyond social media. When working with bloggers to create original content, it's likely that they have their own site where 
they can promote their content as well. This is an excellent opportunity to improve site ranking, by generating high-quality backlinks for your website. When these influencers create content and link to a site, this generates a high-quality backlink for that site.

Online communities are easily created and managed and their role is a very important one. In order to ensure a perfect connection between people from the same sphere of interest, only certain members have to be added. They must be encouraged to create valuable content for that particular group, post only for the benefit of the majority of the members, and use a language and type of post that is accepted and understood by all members. A social community it is a virtual expression people to belong to an area of people with same interests, to feel they matter within a community. However, most companies paying for advertising in conventional media think of virtual groups as additional sales channels (Davis, 2015, p. 14).

The idea of the virtual community with a significant role in supporting the activity and the development of a brand is also reinforced by the findings of the study by Kenneth D. Plowman and Beki Winchel, published in 2016. The two go further beyond the purely communicative dimensions at the virtual community level and claim such a community, loyal to the beginning of the branding strategy, can have an important role not only in increasing sales but also in overcoming a crisis situation. If this community is compact enough, thanks to the applicability of a brand and very convinced of its importance in everyday life, community members will be consistent with the brand regardless of the difficult times they pass or will morally support the company in the event of competition attacks (Plowman, Winchel 2016, 122). Each group has a leader. Opinion leaders, unlike any other group members, are people who express their opinions more easily, dedicate more time to the community and its interests, have better technical know-how on operating online interactions and the capacity to pleasantly communicate to the majority of the group members (Tsanga, Zhoub 2005, p. 93).

The eMarketer platform, which provides updated statistical data on online sales and activity (Emarketer.com) reports that by the end of 2017, social networks had recorded over 2.55 billion users. According to statistics, the number of users and the progressively tight relation between brand and customer are influenced by the growing Internet speed and the increasingly advanced mobile technology (Balasubraman, Peterson, Javenpaa 2002). A type of purchasing behavior identified in the online environment is represented by the recommendations within communities and social groups. Their members purchase a product according to their direct interest; however, the opinion of others, who have already tested it, is very important in the decision-making process (tools, accommodation, electronics, household appliances, etc.). Thus, in order to increase their sales, companies must 
show a continuous interest in the activity of these communities. These changes in the organization of sales are determined by the new types of consumption and consumer needs. Online sales also involve support from the manufacturer or the seller. The buyers need to ask questions and receive answers about the product's features and performance. That is why social media interactivity must be included as a benefit in the online communication strategy. Thus, the purchase relation becomes more personal, more interactive and more relaxing. The popularity of the message in social media and brand image depends on the communicator's ability to maintain dynamics, interactivity and to attract public attention to the message as long as possible (Davis 2015, p. 51). If, before social media, brand promotion was more oriented towards the products' benefits of use, in the new context, besides from utility, the experience of others is also involved, having the potential to be critical for the purchasing phase. A brand has to be used to create a valuable experience, and communicating personal experience to others is required for brand promotion and consolidation.

For many social media users, in order to grow their business, the main forms of quantification of success are the number of likes registered per page, the number of share-comments made by the public for each post. These variables are important for achieving short-term goals in the case of conventional public relations, marketing or advertising campaigns. In fact, according to the Facebook algorithm changes in January 2018, the most important thing is to involve the public in promoting posts and interacting with the written content in social media. Basically, the number of page fans has an insignificant impact on the posts and overall impact of the page. If an advertising campaign would only have superficial objectives, based on immediate impressions, it would alienate from the initial or greater goal. Thus, social media objectives should exceed the limit of the figures recorded in a certain timespan. The goals of social media use should be based on both awareness (on an informational level), and action (behavior) (Michaelson, Stacks 2014).

\section{Personal brand, influencers and brand promoters' influencers}

In order to define a successful personal brand, determining the features and defining individuality are paramount. A personal brand is how you sell yourself to others. Recent work on personal branding is based on values and competence that can be used to create a personal branding strategy (Rangarajan, Gelb, Vandaveer 2017, pp. 657-666). Before initiating any personal brand promotion activity in the public sphere, one must know their skills, their character (qualities and flaws) and determine their own development, metamorphosis limits, in order to gain the awareness of the community. In many cases, well-defined and representative communities can influence a person's image and their development direction. To avoid further confusion for the public, a blogger, an opinion leader or an online 
figure must determine their "stage personality" - the beliefs that will dominate their online activity and the ideas on which it will unfold. Personal branding is the situation "when a person succeeds in sculpting a distinctive brand, that person is well-known to the target audience, has long-term staying power in the marketplace, is clearly and meaningfully differentiated from competitors and enjoys a corresponding pay premium for his or her well-knowness" (Rein, Kotler, Hamlin, Stoller 2006).

A blogger, an online opinion leader, must respect the interest of the community already formed and be aware of the responsibility they are taking. Once a personality is created, an opinion leader can benefit from the launch of certain products or services that, in turn, will become recognized and appreciated brands, at the beginning, for the community they target.

Influencers are usually hired to promote one brand on their platforms to their own audience. Social media has allowed this kind of marketing to anyone. Famous athletes, models, actors, musicians or public figures, all can be a personal brand used to influence an audience. They can advertise a brand or product on their social accounts. In 2018's PR strategies, influencer marketing is a great way to build brand image and recognition. With technology quickly advancing, it is easy for consumers to connect online with a brand. Having a friendly face associated with a specific brand will differentiate different companies in the eyes of the consumer. Because of public manipulation methods that can be easily applied online, it is important that everyone takes ownership of their role in this promoting and buying process. The company, the influencer and the consumer all need to hold responsibility and accountability for the end result (Crist 2018).

The value of a personal brand is measured according to the number of registered fans in the social media accounts. Social media platforms allow the customization of the accounts, which become the mirror of the user and even of their desires. Facebook, for instance, remembers and renders in chronology all user actions: LIKE (or any other event represented by an icon available on the network), SHARE, view or comment. When a person wishes to create another identity, one liked by the public and impressive for the community, he/she must satisfy all the preferences of that alter-ego, regarding the consumption of information. Everything that is related to the personal brand in the online environment, must be similar to public interest and behavior. In the blog, ideas will appear that will be appreciated in social media, and the chosen niche will remain the only segment used for acting towards partnerships and events. This means that, if the person has a passion for cooking, the blog will show recipes, will talk about news in the field, and the partnerships will be in the field of hotel and restaurant services, with chefs, manufacturers, processors or distributors of basic foods. For the positive brand management in social media, one must avoid posting of negative comments 
as much as possible (Krush 2013). To have a long-term online presence, while building it, that is, for at least six months, negative or malicious comments should be set aside, as they can affect the overall image and could be used as negative arguments, in the future, by competitors on the market.

One of the most popular myths in Public Relations, namely "negative advertising is all advertising," can have positive effects only in established cases of already well-known persons (Mickie Kennedy 2010). All information written about a person were at one point indexed by Google. According to Forrester Research Inc., 93\% of online experiences begin by identifying the person or the product through Google, as a search engine (Forrester Research). In order to identify future information that will appear online and will be indexed by Google, the Google Alert tool can be used; this tool issues a warning when the name of the brand for which the alert is set appears online. By being aware of all the positive and negative posted information, it is easier to define a brand's image. A substantial online image involves the exclusive existence of positive information or negative information that is not detrimental to the image of the person or product (Hoffman). In order to ensure a good reputation, the person intending to do so can identify the posts whose subject he or she is representing and remove them. If the post in question was not taken over from the social network and cannot be removed directly, the persons responsible for the negative posts can be contacted and the option of removing unwanted posts can be negotiated with them. The search can be more effective if the most appropriate keywords are used. Thus, the full name, initials, home address, e-mail address, residence city, alias or nickname, if applicable, will be selected. All identified detrimental effects will be inputted for subsequently solving the communication and brand strategy. The removal of images and posts that are unwanted association with the brand is easier if the person only has a social network account (Gale 2018). Unwanted images will be removed, along with the tags applied by other users, friends or not. In the security settings of the Facebook account, it is recommended to only allow viewing by the owner of the account and his/her friends or certain friends. It is known by any online marketer that connecting with various groups of interest will be possible after the launching of the brand and will be required for its presentation in the public space. Also, one of the most important social media activities is revising the contact list and removing unwanted friends.

\section{Management of online partnership}

\section{Possible Strategy Errors}

The most detrimental online thing for a brand or product is the absence of interaction with the customer. If the customer's only connection with the product is in the virtual realm, the product cannot be touched or explored as in a physical store. 
What is interesting about well-known brands on social media, is that the public consumes them in a subjectively, instinctively, depending on the situation, in the context created by the community the consumers are part of which is defining for the personality of the consumers. The products one claims to consume define one as an individual within a certain social setting (Davis 2015, p. 120). Brand consumption is an ongoing process. The true challenge is keeping the target audience interested in the brand for as long as possible. Discussions about the brand must be generated for a longer period of time, in order to ensure long term feedback dynamics between the brand and the public. The higher the impact of the message in all massmedia, from the perspective of quantity, the more it can be said that it became viral (Breazeale 2009, pp. 297-318). The message and brand image going viral depends on the capacity to maintain interactivity. The relationship between information and interactivity is also very important, especially in the context of social media where information and social relationships are dynamic elements of the continuous communication process involving interaction (Ariel, Avidar 2015). Well established companies, with well-defined brands on the market, should trust customer satisfaction regarding the quality of the product and let communities decide how to act in relation to the product. Communities and customers have the role of evaluating the product. There are researchers who define social media as "spreadable media" to describe better its nature as a platform of active engagement in spreading content (Jenkins, Ford, and Green 2013). In such situations, the brand creator or owner is not directly involved in the communication with potential customers, with the target audience. For those operating in the field of online marketing, sociability and interaction are mandatory targets to be achieved and maintained because they contribute to maintaining the level of business growth. The goal, regardless of the domain in which it works, is to increase interactivity and spread the content delivered to social media platforms (Solis, Breakenridge 2009, p. 154).

The brand acts like a deep and long-lasting connection, surpassing physical fulfillment. Thus, the brands promoted very successfully on social networks are those that fulfill the needs of community members. It is also important to mention brand quality and usefulness in the promotional message, however, compared to the emotional, the latter will prevail in the consumer's brand selection. The final decision is determined by consumer behavior and the choices of most community members. For instance, Samsung is a brand that is famous for the quality of its products. In one of the commercials, made in March 14th 2018, in India, in wich the company develop emotional aspects, such as the mother-daughter connection, when using together a high-performance refrigerator: "A Refrigerator that cares for you non-stop, just like your Mom does. Presenting the all-new Samsung Digital Inverter Refrigerator, that runs on your home inverter even during power cuts" (Youtube). As of June 2018 the posting has over 50,460,000 views. 
This way, the brand sales goal is no longer obviously profit oriented, but apparently targets its alignment to certain emotional needs, to bring joy to customers. And the association of the product with positive, successful, glamorous feelings stimulates the public's behavior in favor of the brand, causing the purchase.

Social media branding campaigns can also fail, particularly when using incorrect communication channels. Mistakes are the inability to post multimedia content, tailored to the target audience's consumer behavior and also the lack of interaction on public's feedback (Hipb2b.com, Infographic). Social media is a communication channel with a large audience, where users express themselves freely and critically if the situation so requires. This is why it is important that the audience enjoy the first contact experience with the brand's image. The message must be attractive for the target audience. These ideas have already been brought to the attention of social media professionals by several researchers and practitioners in the field. Malcolm Gladwell, a former business and science writer at Washington Post who wrote in his landmark bestseller, Blink: The Power of Thinking Without Thinking: "Buyers make most decisions by relying on their two-second impressions based on stored memories, images and feelings" (Gladwell 2005). That's why the image, message or title of a post, a brand campaign must be well thought out and very attractive.

Practice is also valid for small businesses and personal brands, as demonstrated by Sue Cockburn, a Canadian website designer and a social media marketer, founder and CEO of Growing Social Biz. She says that for small businesses, how consumers view us or judge us is often determined, like with people, by outward appearances. Before they look deeper, it matters the things that are obvious right away. Branding is about how people see you and first experience you. First impression lasts and it influences the business by attracting new clients, keeping them coming back and telling others about you (Cockburn 2014). It is very easy for a brand to attract public criticism, and once it does, the critiques will stay associated to that brand. If this happens, certain steps need to be taken to save the brand's reputation. This is a difficult process, which involves additional investments.

A major error in brand building is the lack of promotion strategy in the social media campaign (Womack 2017). According to political strategist, and business/ marketing consultant at Womack Consulting Group, campaigns without a properly determined communication strategy in social media fail to send a straight message to the audience. The strategy must include: the message with distinctive messages compared to other products from the same market; measurements and periodical result analyses; a social media adapted policy and an implementation schedule.

The simultaneous creation of several types of accounts on different social media channels in the period after the brand is launched, is also a branding strategy error (Marx 2018). The risk involved by opening multiple accounts: Facebook, Pinterest, 
Twitter or Instagram is the incapacity to create original content on all those communication channels. Rarely operated social media accounts, that do not connect with the public and ones that have old posts on the first page create the impression the brand is not organized or is not interested in establishing a relation to the public. At the same time active and very active brands in social media, with diverse content and liking of consumers in the brand niche, attract the audience's sympathy. This theory is supported by Adweek's top ten American brands published in July 2015. In the article, 10 Brands Doing an Amazing Job on Social Media, Michael Patterson, digital marketing specialist, classifies Oreo and Netflix on second and third place for creating amazing content (Oreo) and understanding the audience (Netflix) (Patterson 2015). It is important for the impact on social networks to establish an actual and constant network of fans, who can connect to each other, from the perspective of their interest and involvement in brand promotion, and in this context, buying fake fans would also be a strategy error (Ehrhardt 2018). Distributing content with typos and/or phrasing errors, regardless of the quality of the information, will be detrimental for the author and affect brand image. In order to build a personal relation with the brand, it is recommended to provide ongoing feedback on the business page to the reactions received from the public, regardless of their tone and nature. Humanizing a brand will ensure the public's involvement for a longer period of time.

\section{Case study. Branding strategy in 2003-2004. The power of the EBS brand, risky associations and developing brand attachment.}

The case study follows the evolution of EBS from its establishment to rebranding. I interceded in this study fragments from the exclusive interview with EBS CEO, Daniel Metz. The interview sought to highlight how a company has turned into a brand due of the way in which the online promotion opportunities have been speculated. The transformation was also due to the way these opportunities were speculated, due to the CEO's proven entrepreneurial status.

In 2000-2002, internet access was rather problematic in Romania. Dial-up connections were used and few computers were able to handle internet searches and website accessing. The social media was out of the question. At the time, Yahoo Messenger was the most accessed chat system connecting the world. Basically, an ancestor of social media. In the next eight years, to raise awareness, a brand had to choose between public display spaces, conventional media advertising and public activities targeting certain audience segments: campaigns and games at the seaside or snow fests in resorts with proper infrastructure and a significant number of tourists, festivals in parks and city centers for children, parents and young people, contests and sports competitions. One of the brands in Cluj, with over 15 years of history, that went through a significant rebranding process is EBS, a software com- 
pany founded in 2002 by Mr. Daniel Metz. Throughout its existence and to date, the same person has been in charge of displaying and transforming this brand, namely Mr. Daniel Metz, who is currently CEO of NTT Data Romania.

Mostly out of instinct, a phased branding strategy was designed for EBS, so that this name would be deeply anchored in the community of Cluj, although it did not represent a mass consumption good and targeted a very small niche. The goal of raising awareness was to gain a level of respect from the community, attractiveness for future employees and partners, and the development of attachments from employees, who would remain loyal to the company. In two cases during the history of this brand, associations were apparently destructive and very risky, yet, in the end, they proved most profitable for growing the power and awareness related to the EBS brand.

Based on the data from the interview, EBS Romania was founded by Daniel Metz in June 2002. He remained the company's CEO until June 2016, when the brand changed its name to NTT Data, after EBS was sold to the Japanese company, NTT Data. Daniel Metz left Romania following the revolution of 1989 that toppled the Communist regime. He returned around 1990 with an experience that would prove useful when launching on the market the largest foreign capital company in Cluj-Napoca. The first client of EBS Romania was a German company, NTT Data, interested in the products provided by the company from Cluj.

In order to increase sales, the company needed to build a name. In 2003, there were no PR or branding specialists on the Romanian marketing, the country was undergoing an initial economic development. The brand needed power, and EBS owner's intuition, through his experience in sales, led to the identification of clear targets for building awareness. This was both necessary in Romania, in order to draw in skilled employees, and abroad, to win new clients. At the border between marketing, advertising and sales lie partnerships and associations. The EBS name was intuitively associated with well-known IT companies at that time. Associations have been largely intuitive. The EBS brand strategy was based, first of all, about the creation of important associations with names in which players were known on the global market. These associations were important to increase the company's prestige in the domestic market and the level of professionalism, at least theoretically, in the perception of future customers. An equally important factor in brand strategy was the intention of EBS leadership to attract confidence and develop the sense of security of their own employees. The idea of such a brand strategy implemented by CEO EBS was unique in 2003-2004 on the Romanian market.

"I read a few publications from abroad and started what we would call today the branding strategy. We had no name on the market, particularly the national one. This was important for both clients and employees. So I found a way to associate EBS with established brands from the international IT market. At the time (2003-2004), I had estab- 
lished partnerships between between EBS and renowned companies, promising that we would use their technologies: Microsoft and Oracle, for instance. For us, a small brand, these names had impact. I have the partnerships with these companies and their logos in every visual tool used by EBS and this has made a huge difference" (Daniel Metz, CEO of NTT Data).

Regardless of the field, a brand is more attractive and easier identifiable on the market if it has a unique feature. Whether it is an ingredient used for the first time in the field or a certain manufacture or human resources policy, the brand can gain visibility if such unique component is properly exploited. In the case of EBS Romania, the management invented a niche that did not exist at the time, claiming that the company was Number 1 within that niche, in Romania. The trust of employees and clients grew significant. It was a unique business management system, with all the modules needed in an industrial enterprise, ERP. Thus, the first ERP system was created for the Romanian industry.

\section{The importance of community specifics for brand stability}

For the stability of a brand and for developing its image, the environment where it exists, the specifics of the settlement and the people targeted for building a reputation are important. Although in neither of the two cases (EBS and NTT Data) the CEO did not target particularly clients from the community of Cluj, he wanted to create among this community a positive brand image, empower them and gain prestige, for the sake of business.

"Cluj has a specific character. There is a wide social group of young people, who make up the academic environment. I noticed that, in Cluj at least in the field of technology, many people come from all over the country to study and pursue a career in IT. I believe that the city also becomes more colorful due to these young people, more or less wise, curious to discover something new, to get educated. This is a state of mind that sets Cluj apart from other cities. At the same time, for the IT, industries, the places available in faculties are insufficient. The demand for jobs is not reflected in the offer. However, universities have insufficient graduates, compared to the employment demand from the IT companies in the city" (Daniel Metz).

Identifying the peculiarities of the community in which the brand develops can help not only to guide the strategy but also to identify new directions. Five years later, in 2009, Lara Lee publishes in Forbes an article on the strengths the community can offer in marketing campaigns. The strengths she identified were developing loyalty, maintaining brand authenticity, stimulating innovation and supporting evolution (Forbes.com, 2009).

Community loyalty and strength to increase the impact of the brand in the society of Cluj was what Daniel Metz was aiming for. The more a brand engages in activities aimed at developing an important goal or edge for a particular com- 
munity, the more the community will contribute to the development of the brand and to a more rapid evolution of its symbolic dimension. What Nike has done to get community loyalty is, to some extent, a strategy that EBS CEO applied. At a competitive time on the American sports equipment market, Nike's management turned its attention to a market segment underestimated from marketing perspectives, namely to amateur sports communities that encouraged the development of women's and girls' abilities. The reward was to increase community loyalty and, implicitly, loyalty to a new market segment. Daniel Metz chose to support an important cultural symbol of the Cluj society and a significant sporting segment for a large part of the city's masculine population.

\section{EBS's association with grey brands}

In the beginning, in order to build brand awareness within the community, EBS was associated with a football team from Cluj and the local opera. The two brands, CFR Cluj and the Romanian National Opera of Cluj-Napoca were, at the time of the association, "grey" brands, without outstanding results at the time. CFR Cluj was in the third division, Divizia $C$, a club with little financial resources. At the opera, employees were protesting in the street, were going on general strike, were refusing to perform shows, and the audience was insignificant, from the perspective of show attendance. The institution was also in a managerial crisis and repeated scandals between the artist's trade union and the leadership appeared in all local media. The funds allocated from the line ministry were fewer, however, the closure of the institution would have been a great loss for society because the Cluj Opera House is a symbol of regional culture and the same time a school where great Romanian artists have learned. Something new was needed, something to offer even more professional satisfaction to the artists. So, the EBS CEO chose to finance a relocation project to move the opera closer to the community, Opera Aperta, for at least one annual performance of the Cluj Opera House in the middle of the community in the city center square. The association with the Cluj Opera brand was finally a fortunate one for EBS. Once things got back on track and the community regained interest in the opera program, the EBS brand gained power, meaning and symbolic value. The opera helped, as a resource of power, in the rebranding process, from EBS to NTT Data.

The situation was similar in the case of the association between EBS and CFR Cluj.

"It was the first year when, as an entrepreneur, I recorded a profit. I wanted to invest in another attractive field for the community, namely football. Cluj had two teams, CFR Cluj, in Divizia C, and U Cluj, in Divizia B. I sent a fax, (at the time, this was the level of technology) to both teams. I offered a few hundred euros, as monthly support for each club. CFR replied immediately. U Cluj never replied. (Daniel Metz). 
Thus, this is how it starts the partnership between EBS and CFR which is still ongoing even în April 2018. Due to the club's performance, later on, both brands EBS and then NTT Data were recognized internationally, as the team reached the European championships. Meanwhile, during the partnership, CFR became a renowned team at European level, with very good results. The two brands, EBS and CFR, went together through periods of satisfactions, but also periods of disappointments, as, at one point CFR, became insolvent. During the trial, when EBS and later on NTT were the strong ones, they were transferring some of this power to the CFR brand which, in turn, when it had international success, it transferred recognition and power to EBS and NTT. During the successful period of CFR, its brand played the most important role in the rebranding process, from EBS to NTT Data. On the stadium, both names of the Cluj-based company were displayed, along with those of the company purchased at the time by NTT Data. The EBS posters gradually became smaller and fewer, in favor of the new brand, NTT. Although a three-year period was assigned for the rebranding process, Daniel Metz, as CEO of NTT Data and owner of EBS, reduced this period to two years, because there was the danger of NTT permanently assimilating the EBS brand. Apparently, the association between EBS Romania and the two brands was less than fortunate or even detrimental for EBS, a brand that was undergoing a financial development. The joining of brands, EBS-Opera and EBS-CFR Cluj, was another intuitive gesture of getting closer to the community, of supporting certain brands/ institutions in need of help and having an audience that was supposed to be representative for the community. In these cases, the choices were based on emotions (personal preferences for the two fields of interest), but also generated new symbolic dimensions for the brand.

\section{Gaining symbolic dimensions for the brand}

Gradually, after gaining reputation on the Cluj market, the visual presence of NTT Data, which was major in the public space, was reduced. The quantity of physical image was abandoned, and the company got involved in an increasing number of social activities, acting on a different level. Thus, the NTT Data started being found as sponsor in events that were representative for the community (concerts, festivals, shows, etc.) The brand gained more and more value, through its charge of positive emotions, good deeds, and implicitly, symbolism. All these aspects are important phases in brand building and gaining recognition. It is assumed that a good and important reputation generates respect and attractiveness, not just from the community, but also from clients, current and future employees. Currently, the IT market in Cluj hosts more and more companies selecting their employees from the same limited number of specialists looking for a job and even undergraduate students. Now (in 2018), when choosing a job, the symbolic value 
of the brand is less important, compared to providing an additional benefit compared to the competitors, but in the future (up to 5 years), selection criteria will change more than we can anticipate.

"We have empirically analyzed the situation and found that we, as an industry, are pressured by the salaries we have to offer, and when certain salary caps will be reached, we will no longer be attractive, from the perspective of the offer and workforce, for the companies abroad. I am positive that, very soon, although we could already be partially living those times, the brand, the image and the reputation of the company will be the attractiveness factors. I am certain that the power of branding will make a difference, within the next five years. The change in the expectations of students today is brand related, but not as much as I expected. For them, today's 1st year students, the most important thing is the attachment to people, particularly to leaders. So it is more complicated than we thought. This is about the brand, but also about the leaders that you grow and train within the company and who, in turn, are and become examples for the groups they work with. A brand is built in the present, so that it can become strong in five years. The right brand and the right leader are a comfort for future employees" (Daniel Metz).

The information provided by Daniel Metz reveal that NTT Data is a stronger brand in Romania compared to Germany, for instance. Then, there are other companies purchased by the Japanese from NTT in Europa and for which the old brands and the new brand have been coexisting for years, without a completed rebranding process.

\section{Conclusion}

I have attempted to support in this chapter the hypothesis that the symbolic dimension built by communicative means ensures the consistency and value of a brand. In this respect, the means offered by digital technology are both varied and efficient. The specialized literature that has been consulted is convincingly proving such an idea. The way you turn your client into a stable partner and the way you cultivate it and keep it attached to the brand is decisive. Thus, influences and brand promoters have a very important role.

The specifics of brand evolution depend in most cases on the person or group that develops it, transfers their personality and value to it, but also on the reaction and specifics of the community where it exists and develops, achieving symbolic dimensions. In the brand development process, informal opinion leaders have the capacity to start a dialog with the public, which is more effective than the use of conventional channels. The article also provides a concise analysis of the impact of online communication technologies on the dialog with the public and, on the other hand, provides guidelines for the use of the online space and strategies for creating and enforcing a brand. On the other hand, on the current stage of online communication and marketing, the role of influencers has become a major value. 
Influenced people in their communities (personal brand) can become influential on certain brands (products or institutions) if they associate or are appropriately associated, in image campaigns, with their respective brands. It is interesting how a certain type of audience offers social power to a person who becomes a personal brand and which in turn can contribute to the cost of increasing the purchasing power of a brand created for a particular community. One can speak here of the hybrid profession: journalist-PR. It has the attributes of a PR specialist (positive formulation, identification of qualities, etc.), but also those of a journalist (objectively apparent exposure, storytelling, arguments in community favor). This new type of activity can be a reorientation solution for traditional media journalists, but it can also be a complex manipulation tool to achieve important revenue from the communication activity. The limited space allocated has forced me to refer only to certain aspects of the concept of brand, a very complex notion with many valences. Future research will also examine other issues where online communication can facilitate the development of a brand.

It also remains a matter of exploring how effective symbolic construction solutions were offered by entrepreneurs without PR and PR experience and lacking support from a PR team. As far as other relevant examples are found (like the EBS examined here), we can further strengthen the hypothesis that authentic entrepreneurial spirit includes certain communicator skills.

Such an idea does not depreciate the appeal to PR professionals. On the contrary, rare cases like the one presented in this article once again confirm the importance of image strategy in the success of a brand. It is once again confirmed that the success of an institution of any kind is not strictly assured by the intrinsic qualities of strictly pragmatic justifications. Success is equally conditioned by extrinsic qualities, the aura of meaning that is added to transform it from a company into a brand.

\section{References}

1. Agius, A. (2015). The 4 Essentials to Building Your Brand on Social Media, April 2015, https://www.entrepreneur.com/article/244677 accessed on September 10, 2017.

2. Akrout, H., Nagy, G. (2018). Trust and commitment within a virtual brand community: The mediating role of brand relationship quality, JN Information \& Management, Elsevier B.V., France, DOI:10.1016/j.im.2018.04.009.

3. Ariel, Y., Avidar, R. (2015). Information, Interactivity and Social Media, Atlantic Journal of Communication, 23 (1), https://www.researchgate.net/publication/272376226_ Information_Interactivity_and_Social_Media.

4. Balasubraman, S., Peterson, R. A., Javenpaa, S. L. (2002). Exploring the Implications of M-Commerce for Markets and Marketing, Journal of Academy of Marketing Science 30, no. 4 . 
5. Forrester Research Inc, https://go.forrester.com/.

6. Breazeale, M. (2009). Word of mouth: An assessment of electronic word-of-mouth research, International Journal of Market Research 51, no. 3.

7. Calder, B. J., Malthouse E., Edward, C. (2005). Managing Media and Advertising Change with Integrated Marketing. Journal of Advertising Research 45, no. 4.

8. Carlin, I. (2005). A Vision of Media Planning in 2010. Journal of Advertising, Research 45, no. 1, https://doi.org/10.1017/S0021849905050075.

9. Cockburn, S. (2014). The Power of First Impressions and Branding, Social Media Today, https://www.socialmediatoday.com/content/power-first-impressions-and-bran ding.

10. Cova, B., Pace, S. (2006). Brand Community of Convenience Products: New Forms of Customer Empowerment-The Case My Nutella The Community, European Journal of Marketing 40, no. 9/10.

11. Crist, M. (2018). Influencer Marketing vs. Social Responsibility, Becoming Business https://ids.uni.edu/becomingbusiness/2018/04/10/influencer-marketing-vs-socialresponsibility/.

12. Crowe, C. (2017). Influencer Marketing: Increasing Your Brand Awareness, Creative Click Media, https://creativeclickmedia.com/influencer-marketing/.

13. Davis, R. (2015). Social Media Branding for Small Business: The 5-Sources Model A Manifesto for Your Branding, Business Expert Press, Revolution.

14. Dodd, M.D., Stacks, D.W. (2013). Organizational Social Media Policies and Best Practices Recommendations, Social Media and Strategic Communications, eds. S. Hanna, Noor-Aldeen and J.A. Hendricks, London: Palgrave MacMillan.

15. Duhe, S., Wright, D.K. (2013). Symmetry, Social Media and the Enduring Imperative of two-Way Communication, Public relations and communication management: Current trends and emerging topics, eds. K. Sriramesh, A. Zerfass and J.N. Kim, New York, Routledge.

16. Emarketer, Social Networking Reaches Nearly One in Four Around the World, http:// www.emarketer.com/Article/Social-Networking-Reaches-Nearly-One-FourAround-World/1009976.

17. Ehrhardt, J. (2018). What's so bad about buying fake Instagram likes?, Influencer DB, https://www.influencerdb.net/blog/whats-so-bad-about-buying-fake-instagramlikes/.

18. Gale, A. (2018). How to clean your online reputation, Management Today, https://www. managementtoday.co.uk/clean-online-reputation/your-career/article/1461422.

19. Gladwell, M (2005). Blink: The Power of Thinking Without Thinking, Little, Brown and Company, New York.

20. Hipb2b.com, Infographic - 8 Social Media Marketing Mistakes to Avoid, https://www. hipb2b.com/blog/infographic-8-social-media-marketing-mistakes-avoid/.

21. Jenkins, H., Ford, S., Green, J. (2013). Spreadable media: Creating value and meaning in a networked culture. New York, NY: New York University Press. 
22. Hoffman, A. How to Clean Up Your Online Reputation, Monster.com, https://www. monster.com/career-advice/article/clean-up-your-online-reputation.

23. Kennedy, M. (2010). The Biggest PR Myth of All: There's No Such Thing as Bad Publicity, ereleases.com, https://www.ereleases.com/pr-fuel/biggest-pr-myth-of-all/.

24. Krush A. (2013). Brand Management on Social Media: Be Different, Positive and Consistent, Social Media Today, https://www.socialmediatoday.com/content/brandmanagement-social-media-be-different-positive-and-consistent.

25. Lee, L. (2009). The Power of Community in Marketing, Forbes, https://www.forbes. com/2009/04/06/lara-lee-community-branding-leadership-cmo-network-marketing.html\#4dae95e73851.

26. Marx, J. (2018). Is too much social a thing? M2 Marketing, https://www.jm2market ing.com/Blog/Details/Why-too-many-social-media-accounts-are-a-bad-thing.

27. Michaelson, D., Stacks, D. W. (2014). A Professional and Practitioner's Guide to Public Relations Research, Measurement and Evaluation, 2nd Ed., Institute for Public Relations, New York, Business Expert Press.

28. Patterson M. (2015). 10 Brands Doing an Amazing Job on Social Media, Adweek, http:// www.adweek.com/digital/michael-patterson-10-brands-amazing-social-media/.

29. -Pascale, A. (2015). 4 reasons you shouldn't be afraid to be funny on social media, 25 May, mashable.com,https://mashable.com/2015/05/28/humor-social-media/\#D0Urhx Ch8Zq1.

30. Percy, L. (2014). Strategic Integrated Marketing Communications, 2nd ed. Hoboken, Routledge.

31. Pew Research Center (2014). The Growth in Digital Reporting: What it Means for Journalism and News Consumers, State of the News Media 2014, http://www.journalism. org/files/2014/03/Shifts-in-Reporting_For-uploading.pdf.

32. Phillips, S. (2007). A Brief History of Facebook, The Guardian, http://www.theguard ian.com/technology/2007/jul/25/media.newmedia.

33. Picard, R. (2010). The Future of the News Industry, Media and Society, eds. J Curran, ed. 5, Bloomsbury Academic, London.

34. Plowman, K. D., Winchel, B. (2016). The Social MediaCommunication Matrix A New Direction in Public Relations, Public Relations Collection, editori Don W. Stacks and Donald K. Wright, Business Expert Press.

35. Rangarajan, D., Gelb, B., Vandaveer, A., (2017). Strategic personal branding- And how it pays off, Business Horizonts, Vol 60, Issue 5.

36. Rein I., Kotler P., Hamlim M., Stoller M. (2006). High Visibility: Transforming your personal and professional brand, New York, McGrow-Hill.

37. Rulsi, M. Evelyn. (2012). Facebook Buys Instagram for $\$ 1$ Billion. The New York Times DealBook,http://dealbook.nytimes.com/2012/04/09/facebookbuys-instagram-for1-billion/?_r=0.

38. Solis, B., Breakenridge, D. (2009). Putting the public back in public relations: How social media is reinventing the aging business of PR. Upper Saddle River, NJ, FT Press. 
39. Statista.com. (2018). https://www.statista.com/statistics/278414/number-of-world wide-social-network-users/.

40. Tsanga, A. S. L., Zhoub, N. (2005). Newsgroup Participants as Opinion Leaders and Seekers in Online and Offline Communication Environments, Journal of Business Research 58, no. 9: 1186.

41. Viner, K. (2013). The rise of the reader: journalism in the age of the open web, The Guardian, http://www.theguardian.com/commentisfree/2013/oct/09/the-rise-of-the-readerkatharine-viner-an-smith-lecture.

42. Youtube. (2018). Samsung add- Samsung Inverter Refrigerator, https://www.you tube.com/watch?v=7SPreqqzv60.

43. Yoo, Chan Yun, Stuhlfaut Mark W. (2013). A tool for evaluating advertising concepts: Desirable characteristics as viewed by creative practitioners, Journal of Marketing Communications, Vol. 19, Issue 2, DOI: 10.1080/13527266.2010.550009.

44. Willey, D. (2018). More Than Awareness: Influencer Marketing's Role In The Sales Funnel, Forbes.com, 28 May, https://www.forbes.com/sites/forbesagencycouncil/ 2018/05/29/more-than-awareness-influencer-marketings-role-in-the-salesfunnel/\#461c9131ace4.

45. Womack, L. (2017). Is Your (Lack Of) Social Media Strategy Killing Your Business?, Forbes.com, https://www.forbes.com/sites/forbescoachescouncil/2017/10/06/is-your -lack-of-social-media-strategy-killing-your-business/\#73f6279d5cf4. 